\title{
The Effect of 24-Epibrassinolide Treatments at Different Concentrations on Some Growth Parameters and Crocin Level in Saffron (Crocus sativus L.)
}

\author{
Yonca Surgun Acar (id) 1,*
}

${ }^{1}$ Department of Agricultural Biotechnology, Faculty of Agriculture, Çanakkale Onsekiz Mart University, Çanakkale, Turkey

\begin{abstract}
Brassinosteroids (BRs) are steroid phyotohormones that play roles in plant growth, secondary metabolite accumulation, stress response, and adaptation. Saffron (Crocus sativus L.) is an important plant with significant pharmacological effects due to its rich phytochemical content. Crocin, the main pigment of the saffron stigma, is a natural food colorant and has anti-cancer activity. In this study, the effects of 24-Epibrassinolide (EBL) at different concentrations $\left(10^{-6}, 10^{-7}, 10^{-8}\right.$ and $\left.10^{-9} \mathrm{M}\right)$ on corm (mother corm) and aerial part related parameters as well as the level of crocin in saffron were investigated. The experiment was conducted in a plant growth cabinet as randomized plots design with 3 replications. 24-Epibrassinolide treatments did not affect the rates of shoot emergence from saffron corms, while $10^{-8}$ and $10^{-9} \mathrm{M}$ EBL treatments increased the number of active nodium and cormlet (daughter corm) as compared to control. All the applied EBL concentrations significantly increased the root and shoot lengths of saffron plants. The maximum number of flowers per plant was observed as a result of the $10^{-8} \mathrm{M}$ EBL treatment. Exogenous treatment of $10^{-9} \mathrm{M}$ EBL enhanced the crocin level by $96.0 \%$ compared to the control. This is the first study to evaluate the effects of BRs in saffron.
\end{abstract}

\section{ARTICLE HISTORY}

Received: March 05, 2020

Revised: April 02, 2020

Accepted: April 23, 2020

\section{KEYWORDS}

Saffron (Crocus sativus), 24-Epibrassinolide, Growth, Crocin.

\section{INTRODUCTION}

Saffron (Crocus sativus L.) is a perennial, sterile and triploid plant that belongs to the Iridaceae family. Both plant itself and spice obtained from dried stigmas are called saffron. Besides being widely used in different industrial areas like food, dye, and cosmetics, saffron is an important plant with pharmacological properties grown since ancient times [1]. Corms of saffron survive for only one season and reproduce only vegetatively by cormlet formation [2]. The flowering time of saffron corms planted in August is known as autumn. C. sativus is grown in Italy, Morocco, Egypt, Greece, Spain, and Turkey and is also cultivated in Azerbaijan, China, India, Pakistan, and Ireland [3]. Saffron is one of the most expensive spices in the world and this is due to the labor in its cultivation process and harvest. A stigma of a saffron is about 2

CONTACT: Yonca Surgun Acar $\bigotimes$ yoncasurgun@gmail.com Department of Agricultural Biotechnology, Faculty of Agriculture, Çanakkale Onsekiz Mart University, Çanakkale, Turkey 
mg and stigmas of around 110.000-170.000 flowers should be collected by hand to obtain one $\mathrm{kg}$ of dry saffron [4].

Chemical analyses demonstrate that numerous seconder metabolites are found in the stigma of saffron containing sugars, minerals, oils, and vitamins as well as terpenes, flavonoids, anthocyanins, and carotenoids [5]. Crocin $\left(\mathrm{C}_{44} \mathrm{H}_{64} \mathrm{O}_{24}\right)$, which gives color to the saffron, picrocrocin $\left(\mathrm{C}_{16} \mathrm{H}_{26} \mathrm{O}_{7}\right)$ which is responsible for taste, and safranal $\left(\mathrm{C}_{10} \mathrm{H}_{14} \mathrm{O}\right)$ that gives flavor, are the most bioactive compounds [6]. Crocin, which constitutes 6-16\% of dry stigma, is a diester and a water-soluble carotenoid [7]. It has been shown in various studies that crocin and crocetin showed inhibitory effects due to their apoptosis-stimulant effect at the beginning and progression stages of various cancer types [8] such as leukemia [9], brain cancer [10], lung cancer [11], and prostate cancer [12].

In vivo and in vitro studies in different plants have revealed that secondary metabolite production is promoted by plant growth regulators (PGRs) [13]. Brassinosteroids (BRs), are a class of polyhydroxysteroids considered as "sixth class plant hormones" [14]. Studies carried out with BR mutants of Arabidopsis thaliana (L.) Heynh: [15] and Pisum sativum L. [16] provided strong proof that BRs are essential for plant growth and development. Brassinosteroids play pivotal roles in a wide range of physiological processes including such as cell division and expansion, gene regulation, protein, and nucleic acid synthesis, photosynthesis, vascular differentiation, seed germination, flowering, and fruit formation as well as increase tolerance against various stress factors [17, 18]. In addition, it has been determined that BRs promote the production of secondary metabolites in different plants [19, 20], however, there are few studies on this subject [21].

The market value of saffron is quite high and demand is increasing for various purposes. On the other hand, saffron production is limited and is gradually decreasing [22]. Therefore, a great interest has emerged in understanding and increasing the biosynthesis and production of saffron carotenoids [23]. In this study, the effects of the EBL hormone on corm and aerial part related parameters as well as the level of crocin in saffron were examined.

\section{MATERIAL and METHODS}

\subsection{Plant Material and 24-Epibrassinolide Treatments}

Saffron (Crocus sativus L.) corms used in this study were obtained from Safranbolu district of Karabük (Turkey) province. The experiment was carried out for three months in the plant growth cabinet in 16 days $\left(23 \pm 1^{\circ} \mathrm{C}\right)$ and 8 hours night $\left(10 \pm 1^{\circ} \mathrm{C}\right)$ period conditions with $50 \pm 2 \%$ relative humidity. In the study, a total of 120 healthy and uniform saffron corms (with an average of $2.5 \mathrm{~cm}$ in diameter) were used. 24-Epibrassinolide (Sigma, Germany) hormone was prepared in accordance with the method of Fariduddin et al. [24] and EBL concentrations used in the study were prepared by the dilution of stock solution. Saffron corms planted at a depth of $1.5-2 \mathrm{~cm}$ in pots $(9 \times 8 \mathrm{~cm})$ containing peat were given $150 \mathrm{~mL}$ of water on the first day and water application of $150 \mathrm{~mL}$ containing EBL hormone in concentrations of $10^{-6}, 10^{-7}$, $10^{-8}$ or $10^{-9} \mathrm{M}$ at intervals of 5 days was carried out. Control samples were given $150 \mathrm{~mL}$ of water every 5 days. A total of eighteen applications were made in three-months. In the experiment carried out in 3 replications in accordance with a randomized block pattern, one corm was planted in each pot and 24 saffron corms were used for each application group.

\subsection{Determination of Growth Parameters}

Shoot emergence $(\%)$ was calculated by recording numbers of shoots spring from saffron corms during the experiment $(\mathrm{n}=24)$. Cormlets $(1 \mathrm{~cm}$ or more in diameter $)$ and the number of active nodiums on corms were determined at the end of the application period. Root and shoot lengths $(\mathrm{cm})$ of saffron were determined by means of a ruler $(\mathrm{n}=15)$. During the flowering 
period, the number of flowers in control and experiment groups was determined by daily count $(\mathrm{n}=15)$.

\subsection{Determination of Crocin Level by High Performance Liquid Chromatography (HPLC)}

\subsubsection{Sample Preparation}

Flowers were collected daily and their stigmas were separated by hand and left to dry in the shade [25]. The extraction of saffron stigmas was carried out in accordance with Zeng et al. [26] method. After stigmas were dried at $40^{\circ} \mathrm{C}$ for 8 hours, they were powdered in a mortar. Then, $4 \mathrm{~mL}$ of methanol was added to stigma samples $(10 \mathrm{mg}$ ) and the mixture was shaken for 4 hours in dark. The final volume was completed to $5 \mathrm{~mL}$ by methanol after the extraction. Samples were then passed through a $0.45 \mu \mathrm{m}$ pore size syringe filters.

\subsubsection{Chromatographic System}

A Shimadzu HPLC system (LC 20A Prominence, Germany) was used equipped with a degasser (DGU-20A3), pump (LC-20AD), autosampler (SIL-20AC HT), column oven (CTO10AS VP), detector (DAD, SPD-M20A), and data communication module (CBM-20AC).

\subsubsection{Chromatographic Conditions}

Quantitation of crocin in stigmas was carried out by UV detection at $440 \mathrm{~nm}$ wavelength using the C18 reverse-phase Inertsil ODS $3(250 \mathrm{~mm} \times 4.6 \mathrm{~mm} ; 5 \mu \mathrm{m})$ column (GL Sciences, Japan). Acetonitrile and ultra-pure water as the mobile phase with gradient elution and mobile phase flow rate was $0.8 \mathrm{~mL} \mathrm{~min}{ }^{-1}$. Injection volume was set at $50 \mu \mathrm{L}$ and column temperature at $25^{\circ} \mathrm{C}$. The retention time of crocin was determined as $5.6 \mathrm{~min}$ in these conditions. Crocin used in the study was obtained from Sigma-Aldrich (Tokyo, Japan) and solvents (HPLC grade) from Merck (Darmstadt, Germany). Crocin concentrations $\left(\mathrm{mg} \mathrm{L}^{-1}\right)$ were given as the mean $( \pm$ SE) of three replications.

\subsection{Statistical Analysis}

Parametric assumptions (normal distribution and homogeneity of variances) for each data set were tested using Shapiro-Wilk and Bartlett's tests. Data obtained from control and EBL hormone treatments were subjected to one-way analysis of variance (ANOVA) and then, multiple comparisons of means were made using Tukey's HSD test. Results are given as mean $( \pm \mathrm{SE})$. The significance level was determined as 0.05 in all analyses.

\section{RESULTS and DISCUSSION}

Biotechnological methods provide large amounts of reproducive material for saffron as well as offering opportunities to produce commercially important chemical substances such as crocin, picrocrocin and safranal [1]. However, micropropagation protocols take a long time, labor-intensive, complex, and not repeatable. Genetic improvement of saffron by means of molecular plant breeding is difficult because it is a triploid $(2 n=3 x=24)$ plant that does not produce seeds [27]. Quality of saffron depends on the content and composition of metabolites, responsible for red color, taste and flavor, which are affected by environmental conditions to which corms are exposed [28]. Modern agriculture is facing several difficulties due to reasons such as a global reduction in soil fertility as well as increasing consumer demands such as pure and high-quality ecological products. For these reasons, alternatives that protect the ecological balance of nature are needed. Plant growth regulators, a product of modern biotechnology, are significant in this respect [29]. But so far, there are very few studies investigating the possible effects of PGRs on saffron [30-32]. To our best knowledge, there is no investigation on the effects of BRs on plant growth and seconder metabolites of saffron. 
In the present study, exogenous EBL treatments did not affect shoot emergence compared to the control, while they caused statistically significant differences in active nodium and cormlet numbers (Table 1). It has been found that the number of active sodium and cormlet numbers varies depending on the EBL concentration. Active nodium number per corm increased by $35 \%$ as a result of the $10^{-9} \mathrm{M}$ EBL treatment. Treatment with $10^{-8}$ and $10^{-9} \mathrm{M} \mathrm{EBL}$ caused an increase in cormlet numbers by $92 \%$ and $70 \%$, respectively. In the field study carried out by Aytekin and Açıkgöz [29], hormone (polystimulin), biohumus, effective microorganisms (EM) or biohumus + EM were applied to saffron corms and an increase in the number of cormlets (an average of 2.47) was obtained in all treatments. In another study about saffron, effects of seven different bacteria isolates as well as indol-3-acetic acid (IAA) and gibberellic acid $\left(\mathrm{GA}_{3}\right)$ on cormlet formation and plant growth parameters were tested. Hormone applications did not result in a significant difference in the parameters about shoot emergence and cormlet (cormlet number, diameter, length and weight) compared to control [30]. Y1ldirım et al. [31] reported that dormancy was broken and numerous cormlets were formed in different sizes of saffron corms which were pre-treated with $5 \mathrm{ng} \mu \mathrm{L}^{-1} \mathrm{BAP}$ and $5 \mathrm{ng} \mu \mathrm{L}^{-1} \mathrm{BAP}+150 \mathrm{ng}$ $\mu \mathrm{L}^{-1} \mathrm{GA}_{3}$ for 150 minutes. While picloram, plays a delaying role in parameters related to nodium activation and corm in saffron among the substances picloram, paclobutrazol or zeatin applied in greenhouse conditions exogenously, the best corm yield was obtained from paclobutrazol $\left(10 \mathrm{mg} \mathrm{L}^{-1}\right)$ application compared to the other treatment groups. Zeatin application $\left(3 \mathrm{mg} \mathrm{L}^{-1}\right)$ caused led to the formation of a high number of active corms (2.81 active nodium/corm) [32].

Table 1. Effects of different concentrations of 24-Epibrassinolide (EBL) hormone treatments on shoot emergence (\%), active nodium (number/corms) and cormlet number (number/corms) in saffron (C. sativus)

\begin{tabular}{cccc}
\hline Treatments & Shoot emergence $(\%)$ & $\begin{array}{c}\text { Active nodium number } \\
\text { (number/corm) }\end{array}$ & $\begin{array}{c}\text { Cormlet number } \\
\text { (number/corm) }\end{array}$ \\
\hline Control & $79.20 \pm 4.20^{\mathrm{a}}$ & $3.76 \pm 0.12^{\mathrm{bc}}$ & $1.52 \pm 0.25^{\mathrm{b}}$ \\
$10^{-6} \mathrm{M} \mathrm{EBL}$ & $70.80 \pm 4.20^{\mathrm{a}}$ & $3.20 \pm 0.15^{\mathrm{c}}$ & $1.05 \pm 0.50^{\mathrm{b}}$ \\
$10^{-7} \mathrm{M}$ EBL & $75.00 \pm 7.20^{\mathrm{a}}$ & $3.13 \pm 0.20^{\mathrm{c}}$ & $1.27 \pm 0.16^{\mathrm{b}}$ \\
$10^{-8} \mathrm{M} \mathrm{EBL}$ & $87.50 \pm 7.20^{\mathrm{a}}$ & $4.03 \pm 0.25^{\mathrm{b}}$ & $2.93 \pm 0.28^{\mathrm{a}}$ \\
$10^{-9} \mathrm{M}$ EBL & $83.30 \pm 4.20^{\mathrm{a}}$ & $5.10 \pm 0.14^{\mathrm{a}}$ & $2.59 \pm 0.22^{\mathrm{a}}$ \\
\hline
\end{tabular}

Values in the table are mean $( \pm \mathrm{SE})$ data. Different letters in the same column indicate significant differences according to Tukey's HSD test $(p<0.05)$.

As all EBL concentrations applied in the present study revealed statistically significant increases in root and shoot length compared to control, maximum values were determined in both parameters consequent to $10^{-8} \mathrm{M}$ EBL treatment (Table 2). Ali et al. [33] recorded that applications of $10^{-9} \mathrm{M}$ EBL and 28-homobrassinolide (HBL, BR analogue) increased root and shoot length in Vigna radiata (L.) R.Wilczek. Similarly, HBL applications at different concentrations $\left(10^{-7}, 10^{-9}\right.$ and $\left.10^{-11} \mathrm{M}\right)$ to Zea mays L. for 7 days led to an increase in root and shoot length compared to control [34]. Brassinosteroids are involved in the cell expansion process with their effects on gene expression and enzyme activity [35]. Besides, this hormone group stimulates cell elongation and cell division which is underlined by physiological ways such as control of modification of cell wall, carbohydrate assimilation and aquaporin activities [36]. On the other hand, EBL treatments have been determined to demonstrate inhibitory effects on root formations in mung bean, wheat, and corn plants [37]. Müssig et al. [38] reported that applications with lower concentrations promote root growth as high concentrations cause an inhibitory effect. Additionally, it shows that roots need less BRs than shoots as BR amount was found to be high in tomato shoots while they were very low in roots [39]. In the present study, 
EBL treatments $\left(10^{-8}\right.$ and $\left.10^{-9} \mathrm{M}\right)$ caused an increase in the number of flowers $(45.0 \%$ and $41.0 \%$, respectively) (Table 2). It was determined in the study conducted by Ghanbari et al. [27] for 3 years that single or combined applications of different types of fertilizers and Glomus mossae, a mycorrhizal fungus, affect flower number in saffron and that organic fertilizer (inoculated with Glomus mossae) is the application which increases the number of flowers most compared to other applications. While EBL hormone $\left(10^{-6} \mathrm{M}\right)$ applied to Capsicum annuum L. by spraying method on day 15,45 and/or 75 did not change the number of flowers compared to control [40], $10^{-8} \mathrm{M}$ EBL treatments performed after $15^{\text {th }}$ and $30^{\text {th }}$ days to Tagetes erecta $\mathrm{L}$. days from planting with the same method led to an increase in the number of flowers [41]. Brassinosteroids affect flower formation by modulating metabolic pathways as well as interacting with other signaling pathways and phytohormones [42, 43].

Table 2. Effects of different concentrations of 24-Epibrassinolide (EBL) hormone treatments on shoot length $(\mathrm{cm})$, root length $(\mathrm{cm})$ and the number of flowers (per plant) in saffron $(C$. sativus)

\begin{tabular}{cccc}
\hline Treatments & Shoot length $(\mathrm{cm})$ & Root length $(\mathrm{cm})$ & $\begin{array}{c}\text { Number of flowers } \\
\text { (per plant) }\end{array}$ \\
\hline Control & $10.87 \pm 0.52^{\mathrm{d}}$ & $2.52 \pm 0.25^{\mathrm{c}}$ & $1.73 \pm 0.04^{\mathrm{b}}$ \\
$10^{-6} \mathrm{M} \mathrm{EBL}$ & $16.73 \pm 0.75^{\mathrm{c}}$ & $4.72 \pm 0.16^{\mathrm{b}}$ & $1.46 \pm 0.12^{\mathrm{b}}$ \\
$10^{-7} \mathrm{M} \mathrm{EBL}$ & $24.59 \pm 1.59^{\mathrm{b}}$ & $7.69 \pm 0.28^{\mathrm{a}}$ & $1.69 \pm 0.13^{\mathrm{b}}$ \\
$10^{-8} \mathrm{M} \mathrm{EBL}$ & $31.62 \pm 2.06^{\mathrm{a}}$ & $8.86 \pm 0.57^{\mathrm{a}}$ & $2.50 \pm 0.21^{\mathrm{a}}$ \\
$10^{-9} \mathrm{M}$ EBL & $24.11 \pm 1.21^{\mathrm{b}}$ & $7.70 \pm 0.17^{\mathrm{a}}$ & $2.44 \pm 0.06^{\mathrm{a}}$ \\
\hline
\end{tabular}

Values in the table are mean $( \pm \mathrm{SE})$ data. Different letters in the same column indicate significant differences according to Tukey's HSD test $(p<0.05)$.

Besides their dynamic roles in the adaptation of plants to their environments, secondary metabolites are important to drug sources [44]. It has been revealed that crocin and its analogues ( $\alpha$ - crocin, crocin-2, crocin-3, crocin-4 and crocin-5) with many biological activities such as anti-tumor, anti-cancer, anti-microbial, anti-inflammatory and antioxidant were more efficient than the other secondary compounds in the therapeutic use of saffron [45]. According to the results of HPLC analysis results in the present study, $10^{-8}$ and $10^{-9} \mathrm{M}$ EBL treatments increased crocin, a natural carotenoid, amount compared to control by $21.0 \%$ and $96.0 \%$ (Figure 1 and Figure 2). Based on the obtained results, we can interpret that the use of EBL in the cultivation of saffron may be one of the important approach for increasing the level of crocin. In this study, it was determined that low-concentration EBL treatments gave more effective results within the investigated parameters. Similarly, studies conducted in different plants have shown that BRs applied at low doses increase product yield and tolerance to different stress factors [46].

In a study in which effects of different culture conditions, carbon sources and PGR on development of callus and crocin level in saffron, it has been revealed that crocin level is increased in mediums containing $30 \mathrm{~g} \mathrm{~L}^{-1}$ sucrose and $20 \mathrm{~g} \mathrm{~L}^{-1}$ starch hydrolyzate as well as IAA ( $\left.4 \mathrm{mg} \mathrm{L}^{-1}\right), \mathrm{GA}_{3}\left(2 \mathrm{mg} \mathrm{L}^{-1}\right)$ or uniconazole $\left(1.25 \mathrm{mg} \mathrm{L}^{-1}\right)$ [47]. Chen et al. [2] obtained three times higher amount of crocin in calluses obtained from the nutrient medium containing $0.5 \mathrm{~g} \mathrm{~L}^{-1}$ 6-benzyl adenine (BA) and $2 \mathrm{mg} \mathrm{L}^{-1}$ IAA hormones using two-stage in vitro culture system. Zeng et al. [26] stimulated the formation of stigma-like structures as a result of the application of sodium acetate in vitro culture, but also caused an increase in the amount of crocin. In addition, it was reported that polyvinylpyrrolidone (PVP) application increases the crocin level in stigma-like structures, as well. In another in vitro study, effects of sodium azide and/or $\mathrm{NaCl}$ applications in two different saffron ecotypes on pharmaceutical content of saffron were investigated. While application with $0.09 \mathrm{mg} \mathrm{L}^{-1}$ sodium azide increased safranal, picrocrocin and crocin amount in both ecotypes, $\mathrm{NaCl}$ applications caused a decrease in the amount of secondary metabolites investigated [48]. 


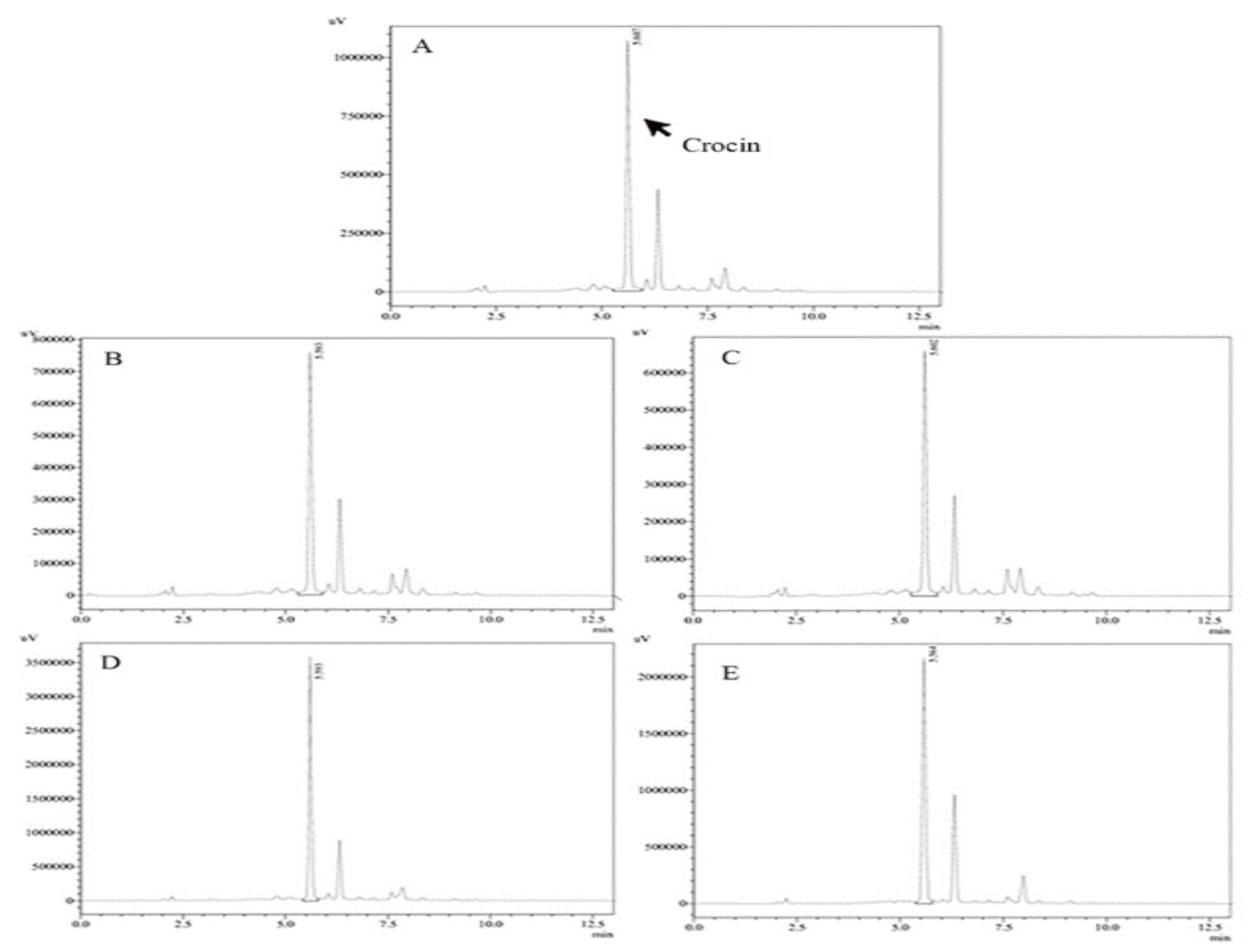

Figure 1. HPLC chromatograms of crocin extracts in saffron (C. sativus) stigmas. A) Control, B) $10^{-6}$ $\mathrm{M}$ EBL, C) $10^{-7} \mathrm{M}$ EBL, D) $10^{-8} \mathrm{M}$ EBL and E) $10^{-9} \mathrm{M}$ EBL treatments.

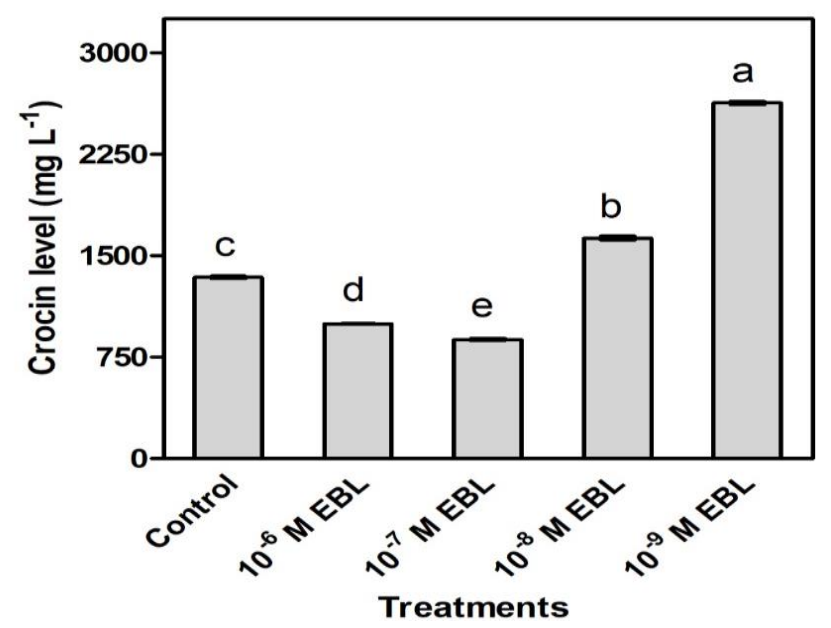

Figure 2. Effect of different concentrations of EBL hormone treatments on the level of crocin in saffron (C. sativus) stigmas. Data given are mean $( \pm \mathrm{SE})$ values $(\mathrm{n}=3)$. Different letters on the bars indicate significant differences according to Tukey's HSD test $(\mathrm{p}<0.05)$.

In the study investigating effects of EBL applications of different concentrations $(0.75$, 1.50 , and $2.25 \mathrm{mg} \mathrm{L}^{-1}$ ) on plant growth and secondary metabolite production in Lavandula angustifolia Mill. (munstead), it has been shown that 0.75 and $1.50 \mathrm{mg} \mathrm{L}^{-1}$ hormone applications increased parameters related to yield as well as total phenolic content and essential oil yield per 
plant [49]. Liu et al. [21] demonstrated that Brassinazole Ressistant 1 (BZRl), which plays a role in BR signalling [50], increases the carotenoid level by regulation carotenoid biosynthesis genes.

\section{CONCLUSION}

When the economic value of saffron is considered, different alternatives are necessary in order to increase its production and secondary metabolite content. In the present study, low concentration EBL treatments in Crocus sativus have led to an increase in active nodium, cormlet, and flower numbers as well as in root and shoot lengths. Another significant finding obtained in the study is the determination of an increase in crocin levels depending on the EBL concentration applied, which requires further investigations. We believe that this study, which is the first one to demonstrate the effects of 24-Epibrassinolide in saffron, will constitute the basis for detailed and comprehensive studies in the future.

\section{Acknowledgements}

We appreciate Senior Biologist Işıl Kesbiç and Dr. Tülden İnanan for their assistance in HPLC analyses.

\section{Declaration of Conflicting Interests and Ethics}

The authors declare no conflict of interest. This research study complies with research publishing ethics. The scientific and legal responsibility for manuscripts published in IJSM belongs to the author(s).

\section{Orcid}

Yonca Surgun Acar (DD https://orcid.org/0000-0002-8684-329X

\section{REFERENCES}

[1]. Çınar, A.S., Önder, A. (2019). Anadolu'nun kültürel mirası: Crocus sativus L. (Safran). FABAD J Pharm Sci., 44(1), 79-88.

[2]. Chen, S.A., Wang, X., Zhao, B., Yuan, X., Wang, Y. (2003). Production of crocin using Crocus sativus callus by two-stage culture system. Biotechnol Lett., 25, 1235-1238. doi:doi.org/10.1023/A:1025036729160

[3]. Molina, R.V., Valero, M., Navarro, Y., Guardiola, J.L., Garcia-Luis, A. (2005). Temperature effects on flower formation in saffron (Crocus sativus L.). Sci Hortic., 103(3), 361-379. doi:doi.org/10.1016/j.scienta.2004.06.005

[4]. Fernandez, J.A. (2004). Biology, biotechnology and biomedicine of saffron. Recent. Res. Dev. Plant Sci., 2, 127-159.

[5]. Gismondi, A., Serio, M., Canuti, L., Canini, A. (2012). Biochemical, antioxidant and antineoplastic properties of Italian saffron (Crocus sativus L.). Am. J. Plant Sci., 3, 15731580. doi:doi.org/10.4236/ajps.2012.311190

[6]. Abdullaev, F.I. (2002). Cancer chemo preventive and tumoricidal properties of saffron (Crocus sativus L.). Exp Biol Med., 227(1), 20-25.

doi:doi.org/10.1177/153537020222700104

[7]. Pitsikas, N. (2016). Constituents of saffron (Crocus sativus L.) as potential candidates for the treatment of anxiety disorders and schizophrenia. Molecules, 21(3), 303. doi:doi.org/10.3390/molecules21030303

[8]. Khorasanchi, Z., Shafiee, M., Kermanshahi, F., Khazaei, M., Ryzhikov, M., Parizadeh, M. R., Kermanshahi, B., Ferns, G.A., Avan, A., Hassanian, S.M. (2018). Crocus sativus a natura food coloring and flavoring has potent anti-tumor properties. Phytomedicine, 43, 21-27. doi:doi.org/10.1016/j.phymed.2018.03.041 
[9]. Sun, Y., Xu, H.J., Zhao, Y.X., Wang, L.Z., Sun, L.R., Wang, Z., Sun, X.F. (2013). Crocin exhibits antitumor effects on human leukemia HL-60 cells in vitro and in vivo. Evid-Based Complementary Altern. Med., 690164. doi:doi.org/10.1155/2013/690164

[10]. Lu, P., Lin, H., Gu, Y., Li, L., Guo, H., Wang, F., Qiu, X. (2015). Antitumor effects of crocin on human breast cancer cells. Int. J. Clin. Exp. Med., 8, 20316-20322.

[11]. Chen, S., Zhao, S., Wang, X., Zhang, L., Jiang, E., Gu, Y., Shangguan, A.J., Zhao, H., Lv, T., Yu, Z. (2015). Crocin inhibits cell proliferation and enhances cisplatin and pemetrexed chemosensitivity in lung cancer cells. Transl Lung Cancer Res., 4(6), 775-783. doi:doi.org/10.3978/j.issn.2218-6751.2015.11.03

[12]. Festuccia, C., Mancini, A., Gravina, G.L., Scarsella, L., Llorens, S., Alonso, G.L., Tatone, C., Di Cesare, E., Jannini, E.A., Lenzi, A., D’Alessandro, A.M., Carmona, M. (2014). Antitumor effects of saffron-derived carotenoids in prostate cancer cell models. Biomed. Res. Int., 135048. doi:doi.org/10.1155/2014/135048

[13]. Jamwal, K., Bhattacharya, S., Puri, S. (2018). Plant growth regulator mediated consequences of secondary metabolites in medicinal plants. J Appl Res Med Aromat Plants., 9, 26-38. doi:doi.org/10.1016/j.jarmap.2017.12.003

[14]. Surgun, Y., Yilmaz, E., Col, B., Burun, B. (2012) Sixth class of plant hormones: Brassinosteroids. C.B.U. Journal of Science, 8, 27-46.

[15]. Li, J., Nagpal, P., Vitart, V., McMorris, T.C., Chory, J. (1996). A role for brassinosteroids in light-dependent development of Arabidopsis. Science, 272, 398-401. doi:doi.org/10.1126/science.272.5260.398

[16]. Nomura, T., Nakayama, N., Reid, J.B., Takeuchi, Y., Yokota, T. (1997). Blockage of brassinosteroid biosynthesis and sensitivity cause dwarfism in Pisum sativum. Plant Physiol., 113, 31-37. doi:doi.org/10.1104/pp.113.1.31

[17]. Sasse, J.M. (2003). Physiological actions of brassinosteroids: An update. J Plant Growth Regul., 22, 276-288. doi:doi.org/10.1007/s00344-003-0062-3

[18]. Bajguz, A., Hayat, S. (2009). Effect of brassinosteroids on plant responses to environmental stresses. Plant Physiol. Bioch., 47(1), 1-8. doi:doi.org/10.1016/j.plaphy.20 08.10 .002

[19]. Ahammed, G.J., Zhou, Y.H., Xia, X.J., Mao, W.H., Shi, K., Yu, J.Q. (2013). Brassinosteroid regulates secondary metabolism in tomato towards enhanced tolerance to phenanthrene. Biol Plant., 57(1), 154-158. doi:doi.org/10.1007/s10535-012-0128-9

[20]. Çoban, O., Baydar, N.G. (2016). Brassinosteroid effects on some physical and biochemical properties and secondary metabolite accumulation in peppermint (Mentha piperita L.) under salt stress. Ind Crop Prod., 86, 251-258. doi:doi.org/10.1016/j.indcrop. 2016.03.049

[21]. Liu, L., Jia, C., Zhang, M., Chen, D., Chen, S., Guo, R., Guo, D., Wang, Q. (2014). Ectopic expression of a BZR1-1D transcription factor in brassinosteroid signalling enhances carotenoid accumulation and fruit quality attributes in tomato. Plant Biotechnol. J., 12, 105-115. doi:doi.org/10.1111/pbi.12121

[22]. Jain, M., Srivastava, P.L., Verma, M., Ghangal, R., Garg, R. (2016). De novo transcriptome assembly and comprehensive expression profiling in Crocus sativus to gain insights into apocarotenoid biosynthesis. Sci Rep., 6, 22456. doi:doi.org/10.1038/srep224 56

[23]. Malik, A.H., Ashraf, N. (2017). Transcriptome wide identification, phylogenetic analysis, and expression profiling of zinc-finger transcription factors from Crocus sativus L. Mol. Genet. Genomics, 292(3), 619-633. doi:doi.org/10.1007/s00438-017-1295-3

[24]. Fariduddin, Q., Khalil, R.R.A.E., Mir, B.A., Yusuf, M., Ahmad, A. (2013). 24Epibrassinolide regulates photosynthesis, antioxidant enzyme activities and proline 
content of Cucumis sativus under salt and/or copper stress. Environ. Monit. Assess., 185, 7845-7856. doi:doi.org/10.1007/s10661-013-3139-x

[25]. Lage, M., Cantrell, C.L. (2009). Quantification of saffron (Crocus sativus L.) metabolites crocins, picrocrocin and safranal for quality determination of the spice grown under different environmental Moroccan conditions. Sci Hortic., 121(3), 366-373. doi:doi.org/1 0.1016/j.scienta.2009.02.017

[26]. Zeng, Y., Yan, F., Tang, L., Chen, F. (2003). Increased crocin production and induction frequency of stigma-like structure from floral organs of Crocus sativus by precursor feeding. Plant Cell Tissue Organ Cult., 72, 185-191. doi:doi.org/10.1023/A:1022215021 613

[27]. Ghanbari, J., Khajoei-Nejad, G., vanRuth, S.M. (2019). Effect of saffron (Crocus sativus L.) corm provenance on its agro-morphological traits and bioactive compounds. Sci. Hortic., 256, 108605. doi:doi.org/10.1016/j.scienta.2019.108605

[28]. Siracusa, L., Gresta, F., Avola, G., Lombardo, G.M., Ruberto, G. (2010). Influence of corm provenance and environmental condition on yield and apocarotenoid profiles in saffron (Crocus sativus L.). J. Food Anal., 23(5), 394-400.

doi:doi.org/10.1016/j.jfca.2010.02.007

[29]. Aytekin, A., Açıkgöz, A.O. (2008). Hormone and microorganism treatments in the cultivation of saffron (Crocus sativus L.) plants. Molecules, 13(5), 1135-1147. doi:doi.org/10.3390/molecules13051135

[30]. Parlakova Karagöz, F., Dursun, A., Kotan, R., Ekinci, M., Yildirim, E., Mohammadi, P., (2016). Assessment of the effects of some bacterial isolates and hormones on corm formation and some plant properties in saffron (Crocus sativus L.). Ankara University Journal of Agricultural Sciences, 22(4), 500-511.

[31]. Y1ldırım, M.U., Özdemir, F.A., Kahriz, P.P. (2016). Safran (Crocus sativus L.) bitkisinde farklı hormon ön muamele ve sürelerinin korm çoğaltımı üzerine etkileri. Tarla Bitkileri Merkez Araştırma Enstitüsü Dergisi, 25(2), 301-305.

[32]. Çavuşoğlu, A. (2017) The effect of exogenously applied plant growth regulators on plant development of saffron (Crocus sativus L.), Iğdır Univ. J. Inst. Sci. \& Tech., 7(1), 17-22.

[33]. Ali, B., Hasan, S.A., Hayat, S., Hayat, Q., Yadav, S., Fariduddin, Q., Ahmad, A. (2008) A role for brassinosteroids in the amelioration of aluminium stress through antioxidant system in mung bean (Vigna radiata L. Wilczek). Environ Exp Bot., 62(2), 153-159. doi:doi.org/10.1016/j.envexpbot.2007.07.014

[34]. Arora, N., Bhradwaj, R., Sharma, P., Arora, H.K. (2008). Effects of 28-homobrassinolide on growth, lipid peroxidation and antioxidative enzyme activities in seedlings of Zea mays L. under salinity stress. Acta Physiol Plant., 30, 833-839. doi:doi.org/10.1007/s11738-0080188-9

[35]. Müssig, C., Altmann, T. (1999). Physiology and molecular mode of action of brassinosteroids. Plant Physiol. Biochem., 37(5), 757-762. doi:doi.org/10.1016/S0981-92 8(99)80042-4

[36]. Müssig, C. (2005). Brassinosteroid-promoted growth. Plant Biol., 7(2), 110-117. doi:doi .org/10.1055/s-2005-837493

[37]. Roddick, J.G., Ikekawa, N. (1992). Modification of root and shoot development in monocotyledon and dicotyledon seedlings by 24-epibrassinolide. J Plant Physiol., 140(1), 70-74. doi:doi.org/10.1016/S0176-1617(11)81060-6

[38]. Müssig, C., Shin, G.H., Altmann, T. (2003). Brassinosteroids promote root growth in Arabidopsis. Plant Physiol., 133, 1261-1271. doi:doi.org/10.1104/pp.103.028662

[39]. Yokota, T., Sato, T., Takeuchi, Y., Nomura, T., Uno, K., Watanabe, T., Takatsuto, S. (2001). Roots and shoots of tomato produce 6-deoxo-28-cathasterone, 6-deoxo-28- 
nortyphasterol and 6-deoxo-28-norcastasterone, possible precursors of 28-norcastasterone. Phytochemistry, 58(2), 233-238. doi:doi.org/10.1016/S0031-9422(01)00237-0

[40]. Samira, I., Dridi-Mouhandes, M.H., Ben, B., Denden, M. (2012). 24-Epibrassinolide ameliorates the adverse effect of salt stress $(\mathrm{NaCl})$ on pepper (Capsicum annuиm L.). $J$ Stress Physiol Biochem., 8(1), 232-240.

[41]. Sagar, A., Kaur, I., Mathur, P., Mukherjee, A., Dhama S., Singh, V., Kaur, J. (2019). A new concept in organic farming: Efficacy of brassinosteroids as foliar spray to ameliorate growth of marigold plants. Environ. We Int. J. Sci. Tech., 14, 25-36.

[42]. Montoya, T., Nomura, T., Yokota, T., Farrar, K., Harrison, K., Jones, J.G.D., Kaneta, T., Kamiya, W., Szekeres, M., Bishop, G.R. (2005). Patterns of dwarf expression and brassinosteroid accumulation in tomato reveal the importance of brassinosteroid synthesis during fruit development. Plant J., 42, 262 269. doi:doi.org/10.1111/j.1365-313X.2005.0 2376.x

[43]. Symons, G.M., Davies, C., Shavrukov, Y., Dry, I.B., Reid, J.B., Thomas, M.R. (2006). Grapes on steroids. Brassinosteroids are involved in grape berry ripening. Plant Physiol., 140, 150-158. doi:doi.org/10.1104/pp.105.070706

[44]. Rao, S.R., Ravishankar, G.A. (2002). Plant cell cultures: chemical factories of secondary metabolites. Biotechnol. Adv., 20, 101-153. doi:doi.org/10.1016/S0734-9750(02)00007-1

[45]. Escribano, J., Alonso, L.G., Prados, C.M., Fernandez, A.J. (1995). Crocin, safranal and picrocrocin from saffron (Crocus sativus L.) inhibit the growth of human cancer cells in vitro. Cancer Letters, 100 (1-2), 23-90. doi:doi.org/10.1016/0304-3835(95)04067-6

[46]. Ali, B. (2017). Practical applications of brassinosteroids in horticulture-some field perspectives. Sci. Hort., 225, 15-21. doi:doi.org/10.1016/j.scienta.2017.06.051

[47]. Xue, L., Zhigang, G., Ruizhi, L. (2002). Effects of culture conditions, carbon source and regulators on saffron callus growth and crocin accumulation in the callus. Tsinghua Sci. Technol., 7(5), 448-453.

[48]. Shahabzadeh, Z., Heidari, B., Dadkhodaie, A. (2013). Regenerating salt tolerant saffron (Crocus sativus) using tissue culture with increased pharmaceutical ingredients. J Crop Sci Biotechnol., 16, 209-217. doi:doi.org/10.1007/s12892-013-0031-8

[49]. Aşçı, Ö.A., Deveci, H., Erdeğer, A., Özdemir, K.N., Demirci, T., Baydar, N.G. (2018). The effects of brassinosteroid applications on growth and secondary metabolite production in Lavandula angustifolia 'Munstead'. Turkish Journal of Agriculture-Food Science and Technology, 6(10), 1448-1454. doi:doi.org/10.24925/turjaf.v6i10.1448-1454.2072

[50]. Kim, T.W., Wang, Z.Y. (2010) Brassinosteroid signal transduction from receptor kinases to transcription factors. Annu. Rev. Plant Biol., 61, 681-704. doi:doi.org/10.1146/annurev .arplant.043008.092057 